Joanna Szkudlarek

\title{
Język psychozy: \\ dadaizm a teoria psychoanalityczna Wilfreda Ruprechta Biona
}

\begin{abstract}
Szkudlarek Joanna, Język psychozy: Dadaizm a teoria psychoanalityczna Wilfreda Ruprechta Biona [The language of psychosis: Dadaism and psychoanalytic theory of Wilfred Ruprecht Bion]. „Przestrzenie Teorii” 29. Poznań 2018, Adam Mickiewicz University Press, pp. 235-249. ISSN 1644-6763. DOI 10.14746/pt.2018.29.8.
\end{abstract}

This paper juxtaposes W.R. Bion's psychoanalytic theory of psychosis with Dadaistic works of art. The aim of this juxtaposition is to enable the reader to better understand Bion's theory of psychosis and to propose a new approach to Dadaistic work from the perspective of psychoanalytic theory. The works of art will illustrate basic psychotic mechanisms. It is a starting point for further elaboration of Bion's theory of thinking and his view on subjectivity. At the same time an original approach towards Dadaistic works of art will be presented, based on psychoanalytic concepts of fragmentation and symbolic equation. Essential differences between creativity and madness will be emphasized.

KEYWORDS: Bion, Dadaism, psychoanalysis, psychosis, language

W historii psychoanalizy Wilfred Ruprecht Bion zasłyną ze swojej pracy klinicznej z pacjentami psychotycznymi i pochodzącymi z niej spostrzeżeniami teoretycznymi ${ }^{1}$. Należał on do grona osób, które przekierowały zainteresowanie psychoanalityków z zaburzeń nerwicowych ku głębszym, psychotycznym zakłóceniom osobowości. Według Biona w przypadku osób psychotycznych „na prawdziwą samoświadomość oddziałuje nie tylko wyparcie i zahamowanie lub atak przez impulsy destrukcyjne, lecz cierpi ona również wskutek niezdolności umysłu do znoszenia doświadczeń emocjonalnych, radzenia sobie z nimi i myślenia o nich” ${ }^{2}$. O współczesnym rozumieniu psychoz, psychotycznej części osobowości i zjawiskach powiązanych pojawiło

${ }^{1}$ Wilfred Ruprecht Bion (1897-1979) był brytyjskim psychoanalitykiem i psychiatra, obok Herberta Rosenfelda i Hanny Segal jednym z najbardziej znanych uczniów Melanie Klein. Jego teoria psychoanalityczna, choć wywodzi się z myśli Klein, wprowadza do niej znaczące modyfikacje. Zarówno koncepcje Biona, jak i jego aparat pojęciowy są szeroko stosowane we współczesnej klinicznej praktyce psychoanalitycznej, choć nie przeniknęły jeszcze do języka filozofii.

${ }^{2}$ M. Lapinski, Search for Truth: Bion's concept of mind, „The Online Journal of the Australian Psychoanalytical Society" 2007, nr 7B, <http://www.psychoanalysisdownunder.com. au/issues/8/papers/107?keywords=search+for+truth>, [dostęp: 19.01.2017].

235 Język psychozy: dadaizm a teoria psychoanalityczna 
się wiele doniesień w literaturze psychoanalitycznej. „Zasadniczo, w psychoanalizie, za wspólny mianownik wszystkich psychoz traktuje się pierwotne zakłócenie libidinalnej relacji z rzeczywistościa; większość pojawiających się objawów (zwłaszcza konstrukcja urojeniowa) jest zgodnie z tym traktowana jako wtórne usiłowania odnowienia więzi z obiektami”’. Psychoza wiąże się $\mathrm{z}$ koncentracją na ustalaniu własnej tożsamości. Próby w tym zakresie nie przynosza jednak oczekiwanych rezultatów - świat osoby psychotycznej i jej poczucie spójności ja wciąż ulega rozpadowi. To rzeczywistość pełna nieprzystających do siebie fragmentów, których integracja wciąż nie może się udać. W wypowiedziach takiej osoby często pojawiaja się trudności w utrzymaniu wątku, niespójne narracje, neologizmy. O ile klinicyści na co dzień spotykają się - w mniejszym lub większym stopniu - z fenomenami psychotyczności, o tyle dla osób, które nie mają styczności z praktyką psychoanalizy, a same są względnie zdrowe, pojęcie psychozy, czy zjawisk psychotycznych, może pozostawać niejasne. Współczesna psychoanaliza zakłada, że w każdej osobowości znajdują się części psychotyczne, jeśli jednak dominuje część niepsychotyczna, zaburzenia nie są łatwe do rozpoznania $\mathrm{w}$ codziennym doświadczeniu. W związku z tym, aby przybliżyć znaczenie stanu psychotycznego, odwołam się nie tylko do opisu zaczerpniętego z literatury, ale także do ilustracji pochodzącej ze świata sztuki. Dzięki temu doświadczenie psychotyczne stanie się lepiej uchwytne dla nie-klinicysty. Będzie to jednocześnie okazja, by dobrze znanym dziełom sztuki przyjrzeć się z nowej perspektywy.

Dociekania Biona odsyłaja przede wszystkim do doświadczenia klinicznego. Autor wielokrotnie zaznacza, że jego pojęcia sa w pewnym sensie puste i trzeba je dopiero napełnić znaczeniem. Sa to pre-koncepcje, wymagające swoich konkretnych realizacji, w rzeczywistości jest ona jednak silnie osadzona w realności sesji analitycznej. Nasuwa się wniosek, że pre-koncepcje te są niemożliwe do zrozumienia przez osoby niepraktykujące psychoanalizy, a zatem, że jego teoria dla osób bez praktyki klinicznej na zawsze pozostanie, w pewnym sensie, niewypełniona znaczeniem. Lektura jego dzieł nie pozostawia jednak wątpliwości, że opisane w nich odkrycia teoretyczne dotykaja kwestii uniwersalnych i istotnych dla podmiotowości w ogóle. Bion zadaje pytania o istotę podmiotowości, jej źródła i możliwości, ostatecznie dochodzac w swoich rozważaniach do oryginalnej konceptualizacji, opartej, w znacznej mierze, nie tylko na dwóch siłach popędowych (miłości i nienawiści), lecz także na popędzie epistemofilicznym - pragnieniu wiedzy.

${ }^{3}$ J. Laplanche, J.-B. Pontalis, Stownik psychoanalizy, przeł. E. Modzelewska, E. Wojciechowska, Warszawa 1996, s. 272. 
Podstawowe rozważania autora dotyczące podmiotowości opierają się jednak na jego wyjątkowym doświadczeniu klinicznym. Aby dotknąć tego rodzaju doświadczenia, zamierzam odwołać się do kierunku artystycznego zwanego dadaimem. Wybór ten jest nieprzypadkowy. Dadaiści korzystali w swojej twórczości ze specyficznych materiałów i posługiwali się nimi w sposób nietypowy $\mathrm{i}-\mathrm{w}$ swoich czasach - nowatorski. Cały dorobek dadaizmu przenika sprzeciw wobec działań wojennych. Bion tworzył swoją koncepcję w tym samym okresie historycznym i osobiście doświadczył traumatycznych wydarzeń na froncie podczas I wojny światowej (podczas II wojny światowej również uczestniczył w działaniach wojskowych, choć nie walczył na froncie $)^{4}$. Zarówno dadaizm, jak i teoria Biona pojawiły się - przynajmniej po części - jako odpowiedź na zniszczenia wojenne. W natłoku wydarzeń „nie do pomyślenia" wyłonił się ruch artystyczny zmierzający do całkowitego odrzucenia racjonalności oraz nowa teoria myślenia.

Aby unaocznić wyjątkowość dadaizmu w ujęciu psychoanalitycznym, warto dokonać zwięzłego przeglądu teorii psychoanalitycznych dotyczących twórczości artystycznej. Zaczaćc można od Freudowskiego pojęcia sublimacji. Ten mechanizm obronny polega na przekierowaniu popędu seksualnego na nowy, nieseksualny cel, którego obiekty mają wysoką wartość społeczną ${ }^{5}$. Jest to jeden z tak zwanych „dojrzałych” mechanizmów obronnych.

Teorie twórczości powstałe na gruncie teorii relacji z obiektem (czyli współczesnej teorii psychoanalitycznej, do której należy też dorobek Biona), zebrane zostały w artykule Césara A. Alfonso i Augusty Wellington ${ }^{6}$. Należy do nich między innymi koncepcja Melanie Klein, która rozumiała udaną twórczą kreację jako rezultat sublimacji w pozycji depresyjnej. Gdy niemowlę jest już w stanie doświadczać całych obiektów (a nie tylko ich odszczepionych części) i zauważa, że ludzie stanowią całości, budzi się w nim strach przed dezintegracją (pochodzacy z obawy przed utratą rodzica, który obdarza dziecko miłościa). Pamięć takiej spodziewanej (lub realnej) utraty towarzyszy człowiekowi w życiu dorosłym, a twórczość artystyczną wykorzystuje on do odzyskiwania utraconych obiektów i łagodzenia wczesnych, depresyjnych lęków.

W przeglądzie psychoanalitycznych koncepcji twórczości nie może zabraknąć również podanego przez Ernsta Krisa jej rozumienia jako regresji w służbie ego - a więc chwilowego cofnięcia się w rozwoju, dzięki któremu ego wzbogaca się w sposób, jaki - bez regresji - byłby dla niego niedostępny.

\footnotetext{
${ }^{4}$ Warto zaznaczyć, że został on odznaczony Orderem za Wybitną Służbę i Orderem Narodowym Legii Honorowej.

${ }^{5}$ J. Laplanche, J.-B. Pontalis, Stownik..., s. 313.

${ }^{6}$ C.A. Alfonso, A. Wellington, Marzenia senne i kreatywność: spotkanie psychoanalityczne oparte na wspótpracy, przeł. J. Szkudlarek, „Biuletyn Polskiego Towarzystwa Psychoterapii Psychoanalitycznej” 2016, nr 24, s. 31-35.
} 
Interesująca jest również perspektywa Wilmy Bucci, wedle której artystów cechuje aktywność łącząca „zdolność do swobodnego integrowania trybów myślenia charakterystycznych dla procesu pierwotnego i wtórnego"7.

Podsumowując ten zwięzły przegląd koncepcji, autorzy konstatuja, że „proces twórczy wymaga dodatkowego poziomu integracji ego i elastyczności w komunikacji”". Warto w tym miejscu przytoczyć jeszcze jedną myśl z dziedziny teorii sztuki. Rozważania Wilhelma Diltheya stanowią inspirację dla późniejszego myślenia psychoanalitycznego dotyczącego twórczości artystycznej ${ }^{9}$. Dilthey w swoich Pismach estetycznych zwrócił uwagę na trwające od starożytności doszukiwanie się podobieństw pomiędzy wyobraźnią poetycką a obłędem ${ }^{10}$. Autor sprzeciwia się temu stanowisku, wprowadzając pojęcie „nabytego kompleksu życia psychicznego” - matrycy organizowania doświadczeń wewnętrznych nabytej podczas interakcji podmiotu ze światem zewnętrznym. Stanowi ona swego rodzaju formę dla kontaktu z rzeczywistościa. Dilthey zauważa, że podczas gdy związki postrzeżeń i obrazów w przypadku szaleństwa rządzą się przypadkowością w stosunku do rzeczywistości zewnętrznej, genialna wyobraźnia poetycka jest w stanie wyłonić z tej rzeczywistości to, co najbardziej istotne.

Z przytoczonych fragmentów wynika, że proces twórczy wymaga dość dojrzałej organizacji osobowości i - choć szaleństwo i twórczość mają pewne cechy przywołujące na myśl ich związki - nie można sprowadzać artefaktów szaleństwa do dzieł sztuki (i vice versa). Dotyczy to również przypadków, gdzie sama treść dzieła sztuki zawiera elementy, które moglibyśmy nazwać

7 Tamże, s. 32.

8 Tamże.

${ }^{9}$ Wydaje się, że Zygmunt Freud dość bezpośrednio inspirował się niektórymi fragmentami Pism estetycznych Diltheya. W jego artykule Pisarz a fantazjowanie z 1908 roku znajdujemy na przykład następujący fragment: „Otóż pisarz czyni to samo, co bawiące się dziecko: tworzy świat fantazji, który traktuje bardzo poważnie, to jest obdarza wielkim uczuciem, jednocześnie odgraniczając go wyraźnie od rzeczywistości. Język niemiecki zachował to pokrewieństwo zabawy dziecięcej z tworzeniem poetyckim, określając takie przedsięwzięcia pisarza [...] jako gry [...]. (Z. Freud, Pisarz a fantazjowanie, przeł. M. Leśniewska, [w:] Teoria badań literackich za granica. Antologia, t. II, cz. I, oprac. S. Skwarczyńska, 1974, s. 509-510). W artykule W. Diltheya Wyobraźnia poetycka $i$ obłęd z roku 1886 znajdujemy z kolei fragment, w którym autor, pisząc o poezji stwierdza, że „Ten rodzaj iluzji, która tutaj zachodzi, można porównać z ta, którą spostrzegamy u bawiącego się dziecka. Sztuka jest grą. Poeta i bawiące się dziecko wierza, dziecko w życie swych lalek i zwierząt, poeta w rzeczywistość swych postaci. A przecież oboje nie wierzą" (W. Dilthey, Pisma estetyczne, przeł. K. Krzemieniowa, Warszawa 1982, s. 15). Jedyną różnicą jest tutaj kwestia, na ile artysta traktuje swoje dokonania jako rzeczywistość. Wnioski Diltheya, wskazujące na pewien paradoks w tej kwestii, przez co wydają się bliskie psychoanalitycznemu ujęciu twórczej zabawy w myśli Donalda Woodsa Winnicotta.

${ }^{10}$ W. Dilthey, dz. cyt. 
„psychotycznymi”. Tak więc dzieła, które omawiać będę w dalszej części tej pracy, moga stanowić ilustrację pewnych właściwości typowych dla stanu psychotycznego, ale nie można powiedzieć, że same w sobie sa produktem psychozy. Choć sami dadaiści nazywali swoją twórczość anty-sztuką i robili, co w ich mocy, by wymknać się tradycyjnemu rozumieniu dzieła - nadal pozostali artystami. Można posłużyć się tu analogią. Powiedzenie „chyba zwariowałam" możliwe jest tylko z poziomu zdrowej części osobowości. Poważnie chora część nie wie, że jest chora - na tym właśnie polega jej dolegliwość. Dada ogłasza wszem i wobec: „chyba zwariowałam”. Wydaje się dodawać do tego: „i bardzo mi z tym dobrze!”. Wypowiedziawszy to zaklęcie, prowadzi - w wystarczająco bezpieczny sposób - do świata szaleństwa, któremu będziemy się teraz przyglądać i za pomocą którego spróbujemy zgłębić pewne fragmenty teorii Biona.

W wypowiedziach artystów znajdziemy wiele odniesień do sytuacji politycznej, krytycznych wobec wojny (,,wszyscy artyści Dada rzeczywiście $\mathrm{w}$ fundamentalnym sensie sprzeciwiali się wojnie"11). Warto w tym kontekście przypomnieć też mit założycielski ruchu, o którym możemy mówić w ten sposób ze względu na dużą ilość, często niezgodnych z soba, relacji dotyczących przebiegu wydarzeń. Według jednej z wersji słowo „dada” zostało wybrane na chybił-trafił ze słownika francusko-niemieckiego za pomoca papierowego noża. Miało to miejsce w Zurychu, w roku 1916 (na „wyspie pokoju pośród krwawego pola bitwy I wojny światowej”"12). Jak stwierdził Hugo Ball: „Dla nas sztuka nie jest celem samym w sobie, ale możliwością adekwatnego postrzegania i krytyki czasów, w których żyjemy" ${ }^{13}$. Kurt Schwitters, komentując jeden ze swoich kolaży, mówił z kolei: „I tak wszystko zostało zniszczone i trzeba było stworzyć nowe rzeczy z fragmentów” ${ }^{14}$. Richard Huelsenbeck wyraził się następująco:

Żadne z nas nie miało ani trochę zrozumienia dla odwagi, której potrzeba, by dać się zastrzelić dla idei narodu, będącej, w najlepszym wypadku, grupą interesów handlarzy futrem lub skóra, a w najgorszym, grupą interesów psychopatów, którzy wyruszyli z „ojczyzny” ze swoimi tomami Goethego w chlebaku, by wsuwać swoje bagnety we francuskie i niemieckie brzuchy ${ }^{15}$.

\footnotetext{
${ }^{11}$ E. de L'Écotais, The Dada Spirit, (tłumaczenie własne), Assouline, New York 2002, s. 9.

${ }^{12}$ Dadaism, ed. D. Elger, U. Grosenick, Koln 2004, s. 8.

${ }^{13}$ The Role of Visual Art in Dada, <https://www.moma.org/learn/moma_learning/themes/ dada> [dostęp: 19.01.2017].

${ }^{14}$ L. Dickerman, Dada: Zurich, Berlin, Hannover, Cologne, New York, Paris, Landover, MA, 2005, s. 159, <https://www.moma.org/learn/moma_learning/kurt-schwitters-merz-picture-32-a-the-cherry-picture-1921>, [dostęp: 19.01.2017]

${ }^{15}$ Cyt. za: Dadaism..., s. 8.
} 
Artyści, kierowani pragnieniem, by „włączyć sztukę w walkę o nową etykę"16, zwrócili się ku bezpośredniemu działaniu, „[...] chcieli mieć wpływ na własne czasy i dlatego podkreślali przede wszystkim «aktywny» element swoich działań. Właśnie z tego powodu Tristan Tzara stwierdził, że Dada ukazywała swoją prawdę poprzez własne działanie"17.

Krytyka wojny doprowadziła dadaistów do wniosku, że wszystkiemu winny jest rozum.

Logika oznacza komplikacje. Logika jest zawsze błędna. [...] Sztuka, w związku małżeńskim z logika, zawsze żyła w kazirodztwie, pochłaniała, zjadała własny ogon, swoje własne ciało, sama ze sobą cudzołożyła..."”18.

Sprzeciwiając się brutalności wojny, mechanicznemu, anonimowemu zabijaniu i cynicznym uzasadnieniom proponowanym przez władze po obu stronach konfliktu, dadaiści porzucili wiarę w racjonalność i zaproponowali „zniszczenie oszustw rozumu oraz odkrycie porządku irracjonalności”"19. Atmosfera irracjonalności rzeczywiście przyświecała całej działalności ruchu. Słynne akcje dadaistów obfitowały w skandaliczne, trudne do wytrzymania dla publiczności prowokacje, pozbawione jakichkolwiek wskazówek umożliwiających ich racjonalne opracowanie - przykładem może być akcja dadaistów paryskich, która odbyła się w Salonie Niezależnych w roku 1920, kiedy to

[...] trzydziestu ośmiu wykonawców odczytywało opublikowane wcześniej w „Biuletynie Dada" manifesty zapisane techniką poszatkowanej typografii [...]. Głośne odczytywanie manifestów, nakładające się na recytację i śpiewy innych wykonawców, było dla publiczności nie do wytrzymania. Na scenę poleciały nie tylko wyzwiska, ale również przedmioty ${ }^{20}$.

Duch irracjonalizmu i prowokacji wyraźnie przenika też wypowiedzi i manifesty dadaistyczne. W swoim drugim manifeście Tristan Tzara stwierdza na przykład: „Piszę manifest i niczego nie chcę. Mówię jednak pewne rzeczy i w zasadzie jestem przeciwny manifestom - tak samo, jak jestem przeciwny zasadom" 21 .

Dada rozbrajała więc racjonalne myślenie, poszerzała do granic możliwości uznawane do tej pory ramy wypowiedzi artystycznych. Co więcej,

${ }^{16}$ The $A B C$ 's of $D A D A$, cz. 1, 05.2007, <https://www.youtube.com/watch?v=EqkIJ0odF$\mathrm{xA} \& \mathrm{t}=2 \mathrm{~s}>$ [dostęp: 19.01.2017].

${ }^{17}$ Dadaism..., s. 7.

${ }^{18}$ T. Tzara, cyt. za: E. de L'Écotais, dz. cyt., s. 10.

${ }^{19}$ Cyt. za: W. Rubin, Surrealism and Their Heritage, New York 1968.

${ }^{20}$ H. Richter, Dadaizm, przeł. J.S. Buras, Warszawa 1983, s. 60.

${ }^{21}$ T. Tzara, Dada Manifesto II, (tłumaczenie własne), 1918, <http://www.arthistoryarchive.com/arthistory/dada/Dada-Manifesto.html> [dostęp: 19.01.2017]. 
kultywowała zupełnie nowe podejście do materiału dzieła sztuki. Kurt Schwitters stworzył cykl prac plastycznych „Merz” (gdzie słowo „Merz” to frywolnie „odcięty” fragment słowa „Kommerzbank”). Obejmuje on szereg obrazów, których cechą charakterystyczna jest specyficzny materiał. Artysta mówi: „nie byłem w stanie tak naprawdę zrozumieć powodu, dla którego bilety, kawałki kory, garderoby, etykiet, przewodów i fragmentów kół, guziki, czy stare odpadki znalezione na strychu i w śmietnikach, nie miałyby być tak samo odpowiednim materiałem dla obrazu, jak farba produkowana w fabrykach" 22 .

Podobny wybór materiału cechował poezję fonetyczna. Były to utwory przeznaczone do recytacji i publikacji, które składały się wyłącznie z przypadkowo połączonych ze sobą głosek (ewentualnie zdań na granicy rozpadu). Charakterystyczną cechą publikowanych utworów była również różnorodność wykorzystanych fontów - istotna była już tylko formalna strona znaków. Znaczące wypchnęło z siebie znaczone. Jak pisał w swoim dzienniku Hugo Ball, „Wiersze fonetyczne wyrażały nasze pragnienie rezygnacji z języka wyeksploatowanego do niemożliwości przez dziennikarstwo. Musimy sięgnać do najtajniejszej alchemii słowa, a nawet i ją porzucić, jeśli poezja ma zachować dla siebie swoją najświętszą domenę" ${ }^{23}$. Język spotkał więc ze strony dadaistów ten sam los, który stał się przeznaczeniem racjonalności w ogóle - został porzucony, ponieważ wykorzystano go jako narzędzie niecnych celów politycznych. W odpowiedzi na horror wojny i w akcie niezgody na przekroczenie wszelkich granic etycznych głównymi narzędziami artystycznymi dadaistów - zarówno w ramach malarstwa, jak i akcji (happeningów), czy poezji - stała się fragmentacja i tworzenie zlepków. Artyści do dyspozycji mieli strzępki słów, materiałów, dźwięków i ponownie konstruowali z nich całości. Ze względu na drastyczne odrzucenie praw logiki i języka budowa tych całości nie opierała się jednak na żadnych określonych zasadach. Chaotycznie skonstruowane, stworzone z fragmentów, zlepione ad hoc całości - to wytwory Dada.

Dadaiści przekraczali granice wszelkich dotychczasowych konwencji artystycznych, każąc na nowo stawiać pytania o to, co się w nich mieści, a co już poza nie wykracza. Ostatecznie ich działania mieściły się jednak w granicach sztuki. Niezależnie od swoich prowokacji pozostawały w ryzach formy; artystycznego spotkania, recytacji, publikacji, wystawy. Można powiedzieć, że choć tworzywem obrazów bywały śmieci, ich płótno nie wychodziło poza granice ram. W treści dzieł dadaistycznych odnajdujemy

${ }^{22}$ Cyt. za: MoMA learning, <www.moma.org/learn/moma_learning/kurt-schwitters-merz-picture-32-a-the-cherry-picture-1921> (tłumaczenie własne) [dostęp: 19.01.2017].

${ }^{23}$ Cyt. za: H. Richter, dz. cyt., s. 62. 
jednak wspomniane wcześniej, charakterystyczne właściwości szaleństwa: nagłe zmiany i załamania wątków, tworzenie neologizmów, występowanie znacznej koncentracji na ustalaniu własnej tożsamości, próby jej określania i tworzenia dla niej ram (w manifestach i wielu sentencjach określających w niezbyt pomocny sposób, czym jest dadaizm) ${ }^{24}$, ciągłe rozpadanie się świata, co do którego istnienia nie ma pewności i próby zintegrowania, za wszelką cenę i w każdy dostępny sposób, tych nieposkładanych, niepasujących do siebie fragmentów ${ }^{25}$.

W reakcji na te same doświadczenia - czasu wojny - Wilfred Bion rozwijał swoją teorię myślenia. Jak twierdzi Lawrence J. Brown, „traumatyczne doświadczenia Biona z I wojny światowej stanowiły ukryty porządek publikowanych przez niego prac psychoanalitycznych"26. Bion porównuje sytuację analityczną z polem bitwy, twierdząc, że w obu sytuacjach celem przeciwnika jest zaatakowanie jasności myślenia, a celem żołnierza jest jej utrzymanie, niezależnie od okoliczności. Brown zwraca uwagę na znaczenie doświadczeń wojennych Biona na przestrzeni całego jego życia: za znamienny uważa fakt, że ostatnie opublikowane przez niego zdanie, zamykające artykuł Czerpanie jak największych korzyści z sytuacji niekorzystnej brzmi: „ta wojna ciagle trwa” ${ }^{27}$. Brown stwierdza też, że pojęcie psychotycznej części osobowości może również wywodzić się z doświadczeń wojennych Biona, podczas których był on wystawiony na doświadczanie odszczepionych części self ciężko straumatyzowanych osób ${ }^{28}$. Spisane przez Biona wspomnienia z wojny zawierają również traumatyczne doświadczenia z pola bitwy. Brown zauważył, że praca Biona nad teorią myślenia (a dokładniej - nad koncepcją funkcji alfa), odbywała się równocześnie z pracą nad pamiętnikami z bitwy pod Amiens ${ }^{29}$. Jak twierdzi Brown:

${ }^{24}$ „To, co nazywamy DADA, to wygłup z nicości, który objął wszystkie wzniosłe pytania” (Hugo Ball), „DADA nic nie znaczy. Chcemy zmienić świat niczym”. „Dada to słońce, dada to jajko, dada to policja policji” (Richard Huelsenbeck), „DADA z tobą rozmawia, jest wszystkim, zawiera wszystko, należy do wszystkich religii, nie może być ani zwycięstwem, ani porażka, żyje w przestrzeni, ale nie w czasie" (Francis Picabia), Dadaism..., s. 15, 17, 23, 90.

${ }^{25}$ Psychologia kliniczna, red. H. Sęk, t. 2, Warszawa 2008, s. 80.

${ }^{26}$ L.J. Brown, Odkrycie funkcji alfa przez Biona: Myślenie pod ostrzałem na polu bitwy $i w$ gabinecie, przeł. J. Szkudlarek, „Przegląd Psychoanalityczny” 2015, zeszyt 1, s. 17.

${ }^{27}$ W.R. Bion, Seminaria kliniczne $i$ inne prace, red. F. Bion, przeł. D. Golec, Warszawa 2013, s. 356 .

${ }^{28}$ L.J. Brown, dz. cyt., s. 18.

${ }^{29}$ Bion rozróżnia dwa podstawowe elementy stanowiące budulec myśli, fantazji i snów. Są to bardziej podstawowe, pierwotne elementy beta - niemożliwe do pomyślenia, stanowiace swego rodzaju zmysłowo-psychiczna „magmę” życia zmysłowo-umysłowego oraz bardziej złożone i zorganizowane elementy alfa. Sam autor następująco definiuje te elementy: „1. Elementy beta. Ten termin reprezentuje najwcześniejszą matrycę, z której wyłaniają się myśli. Składają się na nią cechy obiektu nieożywionego oraz obiektu psychicznego, przy czym te 
Odkrywanie przez Biona funkcji alfa było częściowo stymulowane przez jego pracę nad wspomnieniami z wojny, a pisanie przez niego autobiografii było z kolei wspierane przez jego rosnąca świadomość procesów zaangażowanych w funkcję alfa - te dwa jednoczesne przedsięwzięcia wzajemnie się umożliwiały.

Tak samo jak Isaac Newton musiał wymyślić rachunek różniczkowy, by badać ruchy planet, tak Bion sformułował funkcję alfa, która wyposażyła go w narzędzia pozwalające zrozumieć myślenie psychotyczne oraz pomogła mu w przepracowaniu własnej traumy z I wojny światowej ${ }^{30}$.

W przytaczanym przez Browna poruszającym opisie doświadczeń wojennych Biona - relacjonowanych w trzeciej osobie - natrafiamy na historię, w której ten znajduje się w okopie, pod ostrzałem, wraz z łącznikiem. Łącznik trzyma się blisko Biona i w pewnej chwili pyta go, dlaczego nie może kaszleć.

Bion odwrócił się i spojrzał na bok Sweetinga, gdzie spostrzegł podmuch pary, dochodzacy z miejsca, w którym powinien znajdować się jego lewy bok. Odprysk bomby wyrwał lewą stronę jego klatki piersiowej. Nie było tam już płuca. Bion oparł się o okop i zaczął bezbronnie wymiotować w niekontrolowany sposób. Sweeting zaczą nieustannie błagać Biona, żeby ten upewnił się, że napisze do jego matki. Te prośby zdawały się zniszczyć jego zszargane już nerwy: „och, na rany boskie, zamknij się, krzyczał Bion, poruszony i przerażony” (s. 67). A później: „chciałbym, żeby się zamkną, chciałbym, żeby umarł. Dlaczego on nie umiera?" (s. 68) ${ }^{31}$.

Brown sugeruje, że doświadczenie to sprawiło, iż Bion zrozumiał granice funkcji alfa i jej naturę. Sytuacja ta złożyła się na „sensoryczny ostrzał”, który sprawił, że jedyne, co ten mógł zrobić, to ewakuować to sensoryczne przeładowanie za pomocą wymiotów. Autor uważa też, że opisana sytuacja „posłużyła za wzorzec podanego przez Biona psychotycznego stanu umysłu, gdy mówił: "pacjent czuje się otoczony przez natychmiastowe połączenia, które - teraz zaimpregnowane okrucieństwem - w okrutny sposób łączą ze sobą obiekty"" 32 .

dwa obiekty nie są w żaden sposób różnicowane. Myśli są rzeczami, rzeczy są myślami; i mają one osobowość. 2. Elementy alfa. Ten termin odnosi się do efektu poddania wrażeń zmysłowych działaniu funkcji alfa. Elementami alfa nie są obiekty istniejące w świecie zewnętrznej rzeczywistości, to raczej efekty pracy wykonanej nad doznaniami, które miały odnosić się do tych realnych obiektów. Umożliwiają tworzenie myśli marzenia sennego i korzystanie z nich" (W.R. Bion, Elementy psychoanalizy, przeł. D. Golec, Warszawa 2012, s. 45). Aby elementy beta mogły stać się elementami alfa, muszą zostać poddane modyfikacji - pierwotnie przy pomocy drugiego, myślącego umysłu, który może „użyczyć” swojej modyfikującej funkcji alfa. Jeśli procesy rozwojowe przebiegają w odpowiedni sposób (a więc u osób „zdrowych”), modyfikująca funkcja alfa zostaje zainstalowana w osobowości.

${ }^{30}$ L.J. Brown, dz. cyt., s. 18.

${ }^{31}$ Tamże, s. 22-23.

${ }^{32}$ Tamże. 
Bion często korzysta z metafory układu trawiennego, by przedstawić funkcjonowanie mechanizmów przetwarzania umysłowego. W normalnych warunkach „trawienie” odbywa się nieświadomie i nieustannie. Z procesu tego powstaje budulec snów, fantazji i wreszcie świadomych myśli. Michał Łapiński uważa, że uprawnione jest porównanie „do fabryki, która wykorzystuje surowe materiały (elementy beta), aby ukształtować podstawowe części i człony (elementy alfa), spośród których tylko wybrane idą do produkcji, sa składane i wysyłane” ${ }^{33}$. W ramach tych umysłowych „procesów trawiennych” zachodzą różne zjawiska; rozróżnianie (dobrego od złego), segregacja części użytecznych i fragmentów odpadowych, wyrzeczenie się pozycji omnipotencji (w której wszystko jest możliwe i możliwe do kontrolowania), a także odróżnianie fantazji od rzeczywistości ${ }^{34}$. Przedstawiony powyżej dramatyczny opis wydarzenia traumatycznego ukazuje sytuację, w której funkcja alfa nie może działać prawidłowo. Podmiot wystawiony jest na tak silne oddziaływanie bodźców sensorycznych, że jedyne, co jest $\mathrm{w}$ stanie zrobić z przyjmowanymi elementami, to ich natychmiastowa ewakuacja. Jest to charakterystyczna cecha elementów beta - nie są możliwe do myślenia, można się ich jedynie pozbywać. Możliwe do myślenia są tylko elementy poddane funkcji „umysłowego trawienia” - funkcji alfa.

Jeśli wrócimy teraz do sztuki Dada (która w kontekście autentyczności i plastyczności opisu podanego przez Biona wydaje się rzeczywiście tylko pewną reprezentacja), zobaczymy wiele podobieństw w zakresie cech utworów artystycznych i doświadczenia psychotycznego (czy też traumatycznego $^{35}$ ). Co więcej, będziemy mogli na ich przykładzie zaobserwować pewne mechanizmy opisane przez Biona.

Zacznijmy od przypomnienia uwagi Kurta Schwittersa: „I tak wszystko zostało zniszczone i trzeba było stworzyć nowe rzeczy z fragmentów" ${ }^{36}$. W tym samym miejscu czytamy dalej, że projektem Merz starał się on „stworzyć połączenia, prawdopodobnie pomiędzy wszystkim na świecie”. Artysta wypowiada się o doświadczeniu, które moglibyśmy nazwać fragmentacja: świat uległ rozpadowi (tak samo, jak „Kommerzbank”, z którego „amputowano” fragment „Merz”), a zadaniem podmiotu staje się jego po-

${ }^{33}$ M. Łapiński, dz. cyt.

${ }^{34}$ Tamże.

${ }^{35} \mathrm{~W}$ cytowanym wcześniej artykule L.J. Browna pojawia się interesujacca uwaga dotycząca podobieństw pomiędzy traumą i psychozą. Cechy wskazujące na takie podobieństwo to między innymi osłabiona zdolność do abstrakcyjnego myślenia i śnienia oraz skłonność do fragmentacji. Autor sugeruje ponadto, u ciężko straumatyzowanych osób, „organizację traumatyczną", która w sztywny sposób utrzymuje w całości pokawałkowany umysł i może sprawiać wrażenie niedostępnej dla analizy, tak samo, jak psychotyczna część umysłu. [L.J. Brown, Odkrycie funkcji alfa..., s. 18].

${ }^{36}$ L. Dickerman, dz. cyt. 
nowna integracja. Niestety, zadanie to skazane jest na niepowodzenie ze względu na sposób, w jaki artysta pragnie tej integracji dokonać - usiłując połączyć „wszystko na świecie” i - jak pamiętamy - wykorzystując do tego celu wszystkie materiały, bez żadnej selekcji ('smieci nadają się do tego celu tak samo dobrze jak farby z fabryki). Ponieważ, używając określeń Biona, fragmenty zostały „zaimpregnowane okrucieństwem”, ponowne łączenie może odbywać się tylko w „okrutny” sposób.

W stanach psychotycznych tego typu twory stanowiłyby podstawę tego, co Bion nazywa „dziwacznymi obiektami” ${ }^{37}$, które budzą lęk. Gdyby poszatkowane słowa wycięte $\mathrm{z}$ gazet, odpadki, zużyte bilety i przewody były fragmentami zniszczonego ego (elementami beta) i zostałyby w tak chaotyczny sposób wyrzucone na zewnątrz, powstałe w ten sposób „dzieło” zaczęłoby prześladować swojego twórcę, pochłaniając elementy jego samego. Proces ten doprowadziłby dalej do zlania się części osobowości z tym, na co wyrzucony został dany fragment.

W ten sposób osobowość (w odczuciu takiej osoby) częściowo stałaby się rzecza. Co więcej, osoba taka byłaby zmuszona do wykorzystywania tych dziwacznych obiektów jako prototypów pojęć, matrycy, za pomoca której wytwarzane sa słowa. Słowa takie nie mają jednak statusu symbolu. Tego rodzaju tworzenie słów doprowadza do sytuacji, w której są one mylnie brane za rzeczy ${ }^{38}$. Bion opisuje w ten sposób źródła (to znaczy: fenomeny prowadzące do) zjawiska, jakim jest zrównanie symboliczne, które poddaje badaniu Hanna Segal. Dla jego zilustrowania opisuje ona przypadek pacjenta cierpiącego na schizofrenię, który:

[n]a jedną z sesji w pierwszych tygodniach analizy przyszedł zaczerwieniony i rozchichotany i nie mógł mówić przez cała sesję. Później okazało się, że przed tą sesją był na terapii zajęciowej, na której robił stołek. Przyczyna jego milczenia, rumieńca i chichotu było to, że nie mógł się zmusić, by mi opowiedzieć o pracy, którą wykonywał. Drewniany stołek, który robił, słowo „stołek”, którego musiałby użyć, i stolec, który zostawiał w ubikacji, tak bardzo odczuwał jako jedno, że nie mógł ze mna o tym rozmawiać. Późniejsza analiza ujawniła, że to zrównanie trzech stool - słowa, stołka i odchodów, było w tym czasie zupełnie nieświadome. Świadomy był jedynie tego, że jest zażenowany i nie może ze mną rozmawiać ${ }^{39}$.

${ }^{37}$ E. de L’Écotais określa prace Maxa Ernsta (składające się z wyciętych fragmentów przeglądów technicznych, które następnie były sklejane i pokrywane rysunkami) jako „dziwne obrazy" [strange images], E. de L'Écotais, dz. cyt., s. 16.

${ }^{38}$ W.R. Bion, Po namyśle, przeł. D. Golec, Warszawa 2014. Opisując to zjawisko, Bion często powołuje się na I. Kanta. Uważa on, że „błąd” psychotycznej części osobowości polega na uznawaniu za „rzeczy same w sobie” tego, co tak naprawdę jest „zjawiskiem”.

${ }^{39}$ H. Segal, Teoria Melanie Klein w praktyce klinicznej, przeł. D. Golec, G. Rutkowska, A. Czownicka, Gdańsk 2006, s. 79. 
Bion bada także procesy jeszcze wcześniejsze rozwojowo od zrównania symbolicznego. Opisuje on ideografię, czy też obraz wzrokowy, a więc najwcześniejsze formy proto-myśli. Jeśli w procesie ich wytwarzania naruszone zostana mechanizmy odpowiedzialne za połaczenia między nimi, cały dalszy proces ich tworzenia zostanie zniszczony, a wytworzenie symbolu stanie się niemożliwe ${ }^{40}$. Dobrym przykładem takich wczesnych ideografii są wiersze fonetyczne Dada. Opisując je wcześniej, zwróciłam uwagę na fakt, że istotą tej „poezji” jest wartość fonetyczna i graficzna. W dziełach tych zostają rozerwane związki, które są charakterystyczną właściwością poezji. Nie możemy tu mówić o metaforach czy innych środkach typowych dla przekazu poetyckiego. Co więcej, często nie możemy tu mówić nawet o słowach czy zlepkach wyrazów, które mogłyby nasuwać jakiekolwiek skojarzenia. Zostajemy wystawieni na obrazy wzrokowe i wrażenia słuchowe, które nie wiążą się ani z rzeczywistościa, ani ze sobą nawzajem. Czytając (czy raczej patrząc na) wiersz fonetyczny lub go słuchając, stajemy się świadkami eksperymentalnej próbki zjawiska psychotycznego, polegającego na destrukcyjnym rozerwaniu połączeń.

Sam Bion w zaskakujący sposób odniósł się do Dada (a w zasadzie do słowa „Dada”) w zawiłym przypisie dotyczącym ogołoconych elementów alfa, które powstają wskutek odwrócenia działania funkcji alfa (a więc pozbawiania elementów alfa cech odróżniających je od elementów beta). Autor pisze:

Znaczenie ma tu ogałacanie elementów alfa z cech różnicujacych ją od elementów beta. Modelem może być teoria zakładająca, iż słowo to nazwa naukowego systemu dedukcyjnego, np. „Dada”. Naukowy system dedukcyjny składa się z serii hipotez. System jest stwierdzeniem o istnieniu stałych połączeń między pewnymi elementami. Połączenia i elementy łączone opierają się na pre-koncepcji (wiedza a priori) oraz na urzeczywistnieniach, które dopasowują się do pre-koncepcji, co pozwala na przekształcenie ich w koncepcje. Z kolei koncepcja staje się abstrakcją lub modelem, dla którego można znaleźć kolejne odpowiadające im urzeczywistnienia. Te właśnie skojarzenia, uznane w ramach naukowego systemu dedukcyjnego za powiąane w stały sposób (a samo to twierdzenie sprawia, iż są one połączone w stały sposób w umyśle jednostki), są teraz odrywane od słowa będącego naukowym systemem dedukcyjnym, tak że ostatecznie pozostaje jedynie słowo „Dada”. Nie rozważam społecznej wartości słowa „Dada”, ani też społecznej wersji naukowego systemu dedukcyjnego noszącego tę nazwę. $[\ldots]^{41}$.

Autor stara się wyjaśnić znaczenie i proces powstawania ogołoconych elementów alfa. Zrozumienie tego fragmentu wymaga zastanowienia się nad dwoma poziomami niniejszego cytatu. Po pierwsze, „koncepcja” ogołoconych elementów alfa „,staje się modelem”. Model ten to „naukowy system

${ }^{40}$ W.R. Bion, Po namyśle...

${ }^{41}$ Tenże, Uczenie się na podstawie doświadczenia, przeł. D. Golec, Warszawa 2011, s. 56. 
dedukcyjny" zrównany ze słowem (a więc pozbawiony sieci wzajemnych połączeń pomiędzy poszczególnymi jego elementami). Po drugie, z jakiegoś powodu autor decyduje się na wykorzystanie słowa „Dada” jako słowa, do którego zostaje sprowadzony taki zredukowany system. Możliwe, że autor posłużył się słowem „Dada” przypadkowo - może ono pierwsze przyszło mu na myśl. Wskazywać może na to ostatnie przytoczone zdanie przypisu (Bion nie rozważa „społecznej wartości” tego słowa ani „społecznej wersji naukowego systemu dedukcyjnego noszącego tę nazwę"). Możliwe jednak, że wybór ten nie jest przypadkowy - być może autor daje nam w tym miejscu, niejako przy okazji, pewną wskazówkę na temat swojego rozumienia Dada - jako działalności nadającej się na model ukazujacy odwrócone działanie funkcji alfa - procesu ogołacania ze znaczeń, w którym z całej sieci skomplikowanych połączeń i skojarzeń zostaje samo słowo.

Sztuka Dada dostarcza możliwości wyobrażenia sobie, czym mogą być elementy beta - najbardziej pierwotne części składowe myśli, podstawowy ich budulec, swego rodzaju nieopracowana materia, na której gruncie moga zachodzić dalsze, bardziej skomplikowane procesy psychiczne. Dadaiści ukazują też sposób, w jaki działać moga procesy fragmentacji, koncentracja na utrzymywaniu spójności poprzez ciąłe próby „lepienia” tożsamości z rozsypanych, chaotycznych i niezróżnicowanych fragmentów, bez pomocy obowiązujących reguł języka. Zobaczyliśmy też, że Dada może stanowić przykład odwrócenia działania funkcji alfa. Kiedy myślimy o dadaizmie jako o kierunku sztuki, możemy formułować opinie, czuć wstręt, oburzenie, lub przeciwnie - zachwyt czy lekkość. Niezależnie od osobistych preferencji spróbujmy wyobrazić sobie, że rama sztuki się rozpada. Sposób, w jaki dzieła te zostały stworzone, staje się jedynym wzorcem odnoszenia się do rzeczywistości, a natężenie chaosu, który ze sobą niosa, towarzyszy nam nieustannie. Jak wyglądałby świat, gdyby doświadczenie dezintegracji było permanentnym stanem wewnętrznym i, co więcej, nie dałoby się go werbalnie zakomunikować? Gdyby słowa w naszych ustach zamieniały się w przedmioty, myśli w rzeczy? Gdyby próby tworzenia i odbudowy zawsze kończyły się narodzinami kolejnych prześladowców? Gdyby nie istniała możliwość adekwatnego odróżniania fragmentów ja od nie-ja i moglibyśmy stawać się wszystkim, wszystko mogłoby stawać się nami? Gdybyśmy w wyobraźni „ogołocili” Dada z artystycznych ram, które - mimo usilnych starań artystów - sa jej integralną częścią i zamieszkali w świecie, w którym szalony happening nigdy nie dobiega końca, prawdopodobnie stanęlibyśmy twarzą w twarz ze stanem, którego zbadaniu Wilfred Bion poświęcił swoje życie.

Zestawienie elementów twórczości dadaistycznej z pewnymi aspektami teorii psychoz W.R. Biona miało na celu ukazanie takich fragmentów tej teorii i aparatu pojęciowego, jak elementy beta i alfa, funkcja alfa i dziwaczne 
obiekty. Korzystając z Bionowskiego rozumienia pre-koncepcji i koncepcji, można by powiedzieć, że ilustracja ta jest próbą napełnienia jego pojęć żywym znaczeniem. Zestawienie to pozwoliło też spojrzeć na dzieła dadaistów jako na fenomeny strukturalnie bliskie psychotycznemu sposobowi odnoszenia się do rzeczywistości wewnętrznej i zewnętrznej oraz języka - fenomenem nadal jednak plasującym się wewnątrz ram działalności artystycznej. Aby podkreślić ten aspekt, podkreślona została istotna różnica pomiędzy obłędem a działalnością twórczą. Bion poświęcił znaczną część swojej pracy twórczej na zrozumienie zjawisk związanych ze stanami psychotycznymi. Prawdopodobnie sam doświadczył ich, walcząc na froncie, i wielokrotnie przeżywał je później ze swoimi pacjentami. Zagadnienie psychozy jest kluczowym elementem teorii Biona i jego dobrą ilustrację może stanowić punkt wyjścia do dalszych badań nad jego teorią. Otwarte pozostają także możliwości dalszych badań nad zagadnieniami związanymi z twórczością artystyczną i znaczeniem traumy.

\section{BIBLIOGRAFIA}

Alfonso C.A., Wellington A., Marzenia senne i kreatywność: spotkanie psychoanalityczne oparte na wspótpracy, przeł. J. Szkudlarek, „Biuletyn Polskiego Towarzystwa Psychoterapii Psychoanalitycznej” 2016, nr 24, s. 31-35.

Bion W.R., Elementy psychoanalizy, przeł. D. Golec, Warszawa 2012.

Bion W.R., Po namyśle, przeł. D. Golec, Warszawa 2014.

Bion W.R., Seminaria kliniczne i inne prace, red. F. Bion, przeł. D. Golec, Warszawa 2013. Bion W.R., Uczenie się na podstawie doświadczenia, przeł. D. Golec, Warszawa 2011.

Bion W.R., War Memoirs 1917-1919, ed. F. Bion, London, 1997.

Brown L.J., Odkrycie funkcji alfa przez Biona: Myślenie pod ostrzatem na polu bitwy i w gabinecie, przeł. J. Szkudlarek, „Przegląd Psychoanalityczny”, 2015, Zeszyt 1, s. $16-35$

Dadaism, ed. D. Elger, U. Grosenick, Köln 2004.

Dickerman L., Dada: Zurich, Berlin, Hannover, Cologne, New York, Paris, Landover, MA, 2005.

Dilthey W., Pisma estetyczne, przeł. K. Krzemieniowa, Warszawa 1982.

Freud Z., Pisarz a fantazjowanie, przeł. M. Leśniewska, [w:] Teoria badań literackich za granica. Antologia, t. II, cz. I, oprac. S. Skwarczyńska, Kraków 1974.

L'Écotais E. de, The Dada Spirit, New York 2002.

Laplanche J., Pontalis J.-B., Stownik psychoanalizy, przeł. E. Modzelewska, E. Wojciechowska, Warszawa 1996.

Łapiński M., Search for Truth: Bion's concept of mind, „The Online Journal of the Australian Psychoanalytical Society", $2007 \mathrm{nr} 7 \mathrm{~B},<$ http://www.psychoanalysisdownunder.com.au/issues/8/papers/107?keywords=search+for+truth $>$ [dostęp: 19.01.2017].

Psychologia kliniczna, red. H. Sęk, t. 2, Warszawa 2008. 
Richter H., Dadaizm, przeł. J.S. Buras, Warszawa 1983.

Rubin W., Surrealism and Their Heritage, New York 1968.

Segal H., Teoria Melanie Klein w praktyce klinicznej, przeł. D. Golec, G. Rutkowska, A. Czownicka, Gdańsk 2006.

Tzara T. Dada Manifesto II, 1918, <http://www.arthistoryarchive.com/arthistory/dada/ Dada-Manifesto.html> [dostęp: 19.01.2017]. 
